IRSH 62 (2017), Special Issue, pp. I-22 doi:Io. I0I7/So020859017000645

(C) 20 I 8 Internationaal Instituut voor Sociale Geschiedenis

\title{
Brazilian Labour History in Global Context: Some Introductory Notes
}

\author{
PAULO FONTES \\ School of Social Sciences of the Fundação Getulio Vargas (CPDOC/ \\ FGV), Praia de Botafogo, I90 - sala I422, I4 Andar, Botafogo, \\ Rio de Janeiro, RJ, 22250-900, Brazil \\ E-mail: paulo.fontes@fgv.br \\ A LEXANDRE FORTES \\ Universidade Federal Rural do Rio de Janeiro, Department of \\ History, Av Governador Roberto da Silveira S/N, Nova Iguaçu, \\ RJ, Brazil \\ E-mail: fortes.ufrrj@gmail.com \\ D AVID MAYER \\ International Institute of Social History, Cruquiusweg 3I, IOI9 AT \\ Amsterdam, The Netherlands \\ E-mail: david.mayer@iisg.nl
}

\begin{abstract}
This article introduces the main topics and intellectual concerns behind this Special Issue about Brazilian labour history in global context. Over the last two decades, Brazilian labour history has become an important reference point for the international debate about a renewed labour and working-class history. It has greatly broadened its conceptual scope by integrating issues of gender, race, and ethnicity and has moved towards studying the whole gamut of labour relations in Brazil's history. Furthermore it has taken new perspectives on the history of movements. As background to this Special Issue, this introduction embeds current Brazilian labour historiography in its development as a field and in the country's broader political and social history. Presenting the contributions, we highlight their connections with current debates in Global Labour History.
\end{abstract}


"The winds from the North don't move windmills", so states a verse from Sangue Latino (Latin Blood), an early I970s Brazilian popular song that celebrates a continentalist vision of Latin America. ${ }^{\mathrm{I}}$ Many advocates of Global Labour History tend to believe that, currently, the "the winds from the Global South move windmills" in our field of studies. Moreover, the winds that blow from Brazil seem to be strong. Indeed, over the last two decades, Brazilian labour history has become an important reference point for the international debate about a renewed labour and working-class history. It has been cited as a "best practice" case (often alongside Indian and South African Labour historiographies) and an important instigator of the field of Global Labour History. ${ }^{2}$ Labour historians from Brazil (but also international scholars working on Brazil) have succeeded in greatly broadening their conceptual scope by integrating issues of gender, race, and ethnicity and have moved towards studying the whole gamut of labour relations in Brazil's history with a special emphasis on the manifold interconnections between free and unfree as well as formal and informal labour. This expanding scholarship has also shed new light on "classic" topics, such as strikes, unionism, or the role of labour policies in redefining workers strategies. Scholars have also expanded the geographical scope of their studies, which were originally confined to the main industrial areas (particularly, São Paulo and Rio de Janeiro), thus offering a much more complex picture of Brazil's regional diversity.

Brazilian labour history, at the same time, forms part of a continental, Latin American research community that, during the last two decades, has set out to revive and redefine the study of labour relations, workers, as well as labour and social movements. A recent congress celebrated in $\mathrm{La} \mathrm{Paz}$ (Bolivia) has aimed to bring this continental community together. ${ }^{3}$ The topics of the papers presented there have made clear that, apart from the two major continental centres of labour history - Argentina and Brazil - there is an increasing academic interest in a methodologically and conceptually renewed historical study of labour in a series of other Latin American countries. The conference included themes such as "representations and interpretations of work", "conflicts about work, uprisings, and revolts in pre-industrial periods", "struggles of workers and unions", or "free and unfree labour, slaveries, and their multiple transitions". This short list alone illustrates the degree to which labour history in Brazil can boast having anticipated and greatly contributed to this renewal - particularly in relation to a nuanced analysis of the whole gamut of historical labour relations going

I. "Sangue Latino", composed by João Ricardo and Paulo Mendonça, was a hit by the band Secos e Molhados in 1973 .

2. Marcel van der Linden, Workers of the World: Essays toward a Global Labor History (Leiden [etc.], 2008), p. 3 .

3. Congreso Latinoamericano y del Caribe de Trabajo y Trabajadores, 2-8 May 2017, La Paz, http://ctt2017.cis.gob.bo/inicio; last accessed 7 November 2017. 
beyond the traditional focus on "double-free" wage labourers. ${ }^{4}$ This list also makes clear that Latin American labour history has its own emphases and is not fully equivalent with the research focuses of labour historians in the Global North or in South Asia. For instance - and the contributions to this Special Issue provide several examples - topics of labour movement history are still (or again) running strong, often realized with new questions and approaches. Another difference is the (sometimes acute) "topicality" of the research done in Latin America: the political relevance of issues such as the co-existence of different labour relations or the trajectory of historical movements seems obvious both to scholars and their audiences.

\section{A BRIEF SKETCH OF LABOUR HISTORIOGRAPHY IN BRAZIL}

As in other countries, the development of labour history in Brazil has been closely interconnected with major political conjunctures, economic transformations, changes in the composition of the working class and the collective presence of workers as social and political actors, as well as with shifts in the intellectual perception of this presence. ${ }^{5}$ In the most general sense, industrialization processes and the numerical increase of the group of industrial workers stood at the beginning of this story. Similar to most other countries, labour history in Brazil initially was not an academic practice but tied to labour movements and thus a "collateral" consequence of the

4. For a view of Brazilian labour history as embedded in a continental landscape of research efforts and traditions see: John D. French, "The Laboring and Middle-Class Peoples of Latin America and the Caribbean: Historical Trajectories and New Research Directions", in Jan Lucassen (ed.), Global Labour History. A State of the Art (Bern, 2006), pp. 289-333; James P. Brennan, "Latin American Labor History", in Jose C. Moya (ed.), The Oxford Handbook of Latin American History (Oxford, 20 I I), pp. 342-366; Rossana Barragán and David Mayer, "Latin America and the Caribbean", in Karin Hofmeester and Marcel van der Linden (eds), Handbook Global History of Work (Berlin [etc.], 2017), pp. 95-I 2 I.

5. In this sketch, we will limit the account to the interrelation between labour historiography as an academic field and the country's general history. This is, of course, a reduction of complexity for the sake of brevity. A fuller picture would include the entangled history of Brazilian and international historiographies in that field (as well as relevant political, social, and economic processes involved), i.e. analysing the ways in which Brazilian labour historiography has influenced developments in Latin America and other world regions, and vice versa. Painting such a fuller picture would, however, require a research effort in its own right and thus go beyond the scope of this introduction. More detailed accounts of the history of labour historiography in Brazil can be found in: Michael Hall and Paulo Sérgio Pinheiro, "Alargando a histórica da classe operária. Organização, lutas e controle”, Revista Remate de Males, 5 (1985), pp. 95-I I9; Maria Célia Paoli, Eder Sader, and Vera Silva Telles, "Pensando a classe operária. Sujeitos ao imaginário acadêmico", Revista Brasileira de História, 6 (1983), pp. I29-149; Claudio Batalha, "Os Desafios Atuais da História do Trabalho", Anos 90, I3:23/24 (2006), pp. 87-I04. 
emergence of labour organisations since the late nineteenth century. Up to the late I950s, the most important works on the subject were mostly descriptive narratives by activists, inspired both by the need to preserve the legacy of past struggles and by the interest of the different political currents inside the workers movement in diffusing their particular versions of crucial events. ${ }^{6}$

It was only in the early I960s, particularly in the state of São Paulo, that an academic interest in labour-related topics arose, mainly in sociology (at that moment itself an incipient discipline in Brazil), which focused on three main issues: First, the quickly growing factory proletariat and the origins and composition of this "young" working class; second, the proclivity of this growing working class to being integrated into the corporatist arrangements offered by populism; third, the "legacy" of slavery, which was seen as a system that prevented any possibility of agency and self-consciousness by the slaves, as well as a historical burden causing enormous difficulties for the integration of black people in the capitalist labour market. These works were generally marked by a peculiar combination of Marxism and modernization theories. Their authors deplored the absence of a "strong" and "mature" working class in Brazil, which was attributed to the fact that most industrial workers were recent migrants from rural areas. Migration to the major urban areas was understood as upward social mobility, resulting in a degree of well-being and, at the same time, a series of yet unsatisfied demands, thereby creating the basis for mass manipulation by populist leaders.?

This metanarrative, based on a selective and frequently biased reading of scarce empirical data, has sunk deep roots not only in the academic universe, but also among a broader Brazilian public, especially "opinion makers". In the I970s, it was further developed by contributions from the political sciences, especially those who accused the Brazilian Communist Party

6. The role of those pioneering militant narratives for the development of Brazilian labour history is examined in Claudio Batalha, "A historiografia da classe operária no Brasil. Trajetórias e tendências”, in Marcos C. de Freitas (ed.), Historiografia brasileira em perspectiva (São Paulo, I998), pp. I45-168. For a communist perspective, see Edgard Carone, Movimento operário no Brasil. Vol. I: 1877-1944 (São Paulo, 1979). A classic anarchist account is offered in Edgar Rodrigues, Socialismo e Sindicalismo no Brasil. 1675-1913 (Rio de Janeiro, 1969).

7. Some classical sociological works are: Juarez R.B. Lopes, Sociedade industrial no Brasil (São Paulo, I964), particularly ch. I entitled "O ajustamento do trabalhador à indústria. Mobilidade social e motivação"; Octavio Ianni, O colapso do populismo no Brasil (Rio de Janeiro, I968); Leôncio M. Rodrigues, Industrialização e atitudes operárias. Estudo de um grupo de trabalhadores (São Paulo, I970); Florestan Fernandes, A integração do negro na sociedade de classes (São Paulo, 1964); Fernando Henrique Cardoso, Capitalismo e Escravidão no brasil Meridional. O negro na sociedade escravocrata do Rio Grande do Sul (São Paulo, I962). A good summary of this first moment of academic research on labour in Brazil is offered in Kenneth P. Erickson, Patrick V. Peppe, and Hobart A. Spalding Jr., "Research on the Urban Working Class and Organized Labor in Argentina, Brazil, and Chile: What is Left to be Done?", Latin American Research Review, 9:2 (1974), pp. I I 5-I42. 
(Partido Comunista do Brasil, PCB) and its moderate political strategy in the immediate post-war period of having enabled the survival of the state-controlled union system: Having been illegal during the corporatist dictatorship of the Estado Novo (1937-1945), the PCB was able to quickly gain ground in the unions which had become more independent of state control with the regime's end. Although the PCB was banned again in I947, it continued to exert major influence over the union movement until the beginning of military dictatorship in $1964 .^{8}$

In the late I970s, however, a new wave of industrial conflict and union organizing (still under the conditions of a dictatorship) led to the emergence of "new unionism", a phenomenon that was more participatory and social-movement-oriented than previous experiences, and which played a major role both in Brazil's re-democratization process and the formation of the Partido dos Trabalhadores (PT) in $1980 .{ }^{9}$ This scenario has greatly contributed to radical changes in Brazil's labour historiography. A group of historians at the new and innovative University of Campinas (Universidade Estadual de Campinas, UNICAMP) became the epicentre of initiatives as well as academic and political discussions that led to a much more sophisticated approach to labour history, resulting in more academic respectability and an increasing institutionalization of the field. ${ }^{10}$ This group strongly emphasized the need for dense and strong empirical research, challenging a long-standing essayistic academic tradition in Brazil, not least in historical studies. It is thus no coincidence that, in the context of these new initiatives, the Edgard Leuenroth Archive was established at the UNICAMP, named after an important early twentieth-century labour leader; it became one of the main archives specialized in labour history in Latin America. ${ }^{\mathrm{I}}$

8. For example: Francisco Weffort, "Origens do sindicalismo populista no Brasil (A conjuntura do Após-guerra)", Estudos Cebrap, 4 (1973), pp. 66-105; Luiz W. Vianna, Liberalismo e sindicato no Brasil (Rio de Janeiro, 1976); Ricardo Maranhão, Sindicatos e democratização (Brasil, 1945/ 1950) (São Paulo, I979); Arnaldo Spindel, O partido comunista na genese do populismo. Analise da conjuntura da redemocratização no apos guerra (São Paulo, I980).

9. On New Unionism see, for instance, Margareth Keck, "The New Unionism in the Brazilian Transition", in Alfred Stepan (ed.), Democratizing Brazil: Problems of Transition and Consolidation (New York, 1989), pp. 252-296; Maurício Rands Barros, Labour Relations and The New Unionism in Contemporary Brazil (London [etc.], 1999); Francisco Barbosa de Macedo, "Social Networks and Urban Space: Worker Mobilization in the First Years of 'New' Unionism in Brazil", International Review of Social History, 60: I (201 5), pp. 33-7I.

I0. Not long after that, labour historians in the states of Rio Grande do Sul (based at the Federal University of Rio Grande do Sul) and Rio de Janeiro (based mainly at Federal Fluminense University) also started to play an important role in the further the development of the field.

I I. On the early days of the History Department at Unicamp and the creation of the Edgard Leuenroth Archive, see an interview with Michael M. Hall conducted by Paulo Fontes and Francisco Barbosa de Macedo, published in the journal Estudos Históricos, 29:59 (2016), pp. 8 I $3-846$. 
Closely connected with the political re-democratization since the late I970s, this new historiography on labour shifted its focus away from the populism of the Vargas years (1930-1945; 1950-1954), and the ambiguous role of the communists therein, and back to the First Republic (I 888-I930). Based on the primary sources available at the time, anarchist and syndicalist experiences were reconstructed in the light of recent political events, which witnessed inter alia a sensible call for "autonomy" among organized workers. ${ }^{\mathrm{I} 2}$ Moreover, a strong interest in working-class everyday life, communities, and experiences beyond the workplaces and political organizations started to take centre stage, particularly among historians interested in the late nineteenth and early twentieth centuries. ${ }^{\mathrm{I}}$

Simultaneously, the well-established field of history of slavery engaged in a dialogue with these major changes on more traditional aspects of labour history. The history of slavery was a field that, due to the transcontinental characteristics of both the slave trade and slave-based production, had been well-connected to international debates ever since Gilberto Freyre's Casa-Grande E Senzala (The Masters and the Slaves) from 1933. In the I980s, the international turn towards "agency" was translated into a renewed emphasis on the actions, culture, and experiences of slaves. This revealed "customs in common" between different groups of workers, which shaped not only the political arena of Brazil during the nineteenth century, but also the fundamental configurations in the state-building process. Among the main achievements of this historiography were its highlighting of the ways in which slaves and freed Afro-Brazilian actively used the laws and the courts, and of the way in which enslaved workers were able to imbue their experiences with political meanings. ${ }^{I 4}$

These shared perspectives, approaches, and historiographical problems helped to shape a common academic tradition. In 2009, historians Sidney

I2. That parallel between the new unionism of the late I970s and the early struggles of the first decades of the twentieth century was made explicit in works such as: Kazumi Munakata, "O lugar do movimento operário", in Anais do IV Encontro Regional de História de São Paulo (Araraquara, 1980), republished in Revista História e Perspectivas, 23:43 (2010), pp. 9-40; Amnéris Maroni, A estratégia da recusa. Análise das greves de maio/78 (São Paulo, I982); Edgar S. de Decca, O silêncio dos vencidos (São Paulo, I98I).

I3. Sidney Chalhoub, Trabalho, Lar e Botequim. O Cotidiano dos Trabalhadores do Rio de Janeiro da Belle Epoque (São Paulo, 1986) is probably the most influential work in this perspective.

I 4. See, among others, João José Reis, “A greve negra de I 857 na Bahia”, Revista USP, I8 (1993), pp. 629; Sidney Chalhoub, Visões da Liberdade. Uma história das últimas décadas da escravidão na Corte (São Paulo, 1990); Robert Slenes, Na senzala, uma flor, esperanças e recordações na formação da família escrava (Brasil, sudeste, século XIX) (Rio de Janeiro, I999); Silvia Lara and Joseli Mendonça (eds), Direitos e Justiças no Brasil. Ensaios de História Social (Campinas, 2006). For an appreciative critique of this perspective see Emilia Viotti da Costa, "Experience versus Structures: New Tendencies in the History of Labor and the Working Class in Latin America: What Do We Gain? What Do We Lose?", International Labor and Working Class History, 36 (1989), pp. 3-24. 
Chalhoub and Fernando Teixeira da Silva would summarize its main targets as the demolition of "the Brazilian historiographical Berlin wall". ${ }^{\text {is }}$ While the metaphor seems a little clumsy, what they meant was the need to study and analyse the history and experiences of slaves and "double-free" wage workers as part of the same historical process of working-class formation. They not only rejected the artificial boundaries and chronologies that divided the academic fields, but also envisioned an enlarged conception of "work" and "workers" themselves. ${ }^{16}$

A major point of reference in these studies was E.P. Thompson's work on the relationship between the exercise of hegemony through the law and the subaltern agency based on cultural notions about rights and justice. ${ }^{17}$ The signature of Thompsonian labour history was also visible in a series of studies focused on the often regionally and locally specific forms of paternalistic domination that had existed in Brazil since slavery. ${ }^{\mathrm{I}}{ }^{8}$

As is well known, New Unionism and the PT rose successively to become an alternative political project for Brazil. In 1994, Eric Hobsbawm had already identified Brazil not only as an example among the "newly industrializing countries" that had developed "industrial working classes who demanded workers' rights", but also as one of the few cases that had given birth to "political labour-cum-people's parties reminiscent of the mass social

I5. Sidney Chalhoub and Fernando Teixeira da Silva, "Sujeitos no imaginário acadêmico. Escravos e trabalhadores na historiografia brasileira desde os anos 1980", Cadernos AEL, I 4:26 (2009), pp. I I-49, 44. These ideas had been developed previously by Silvia H. Lara, "Blowin' in the wind. Thompson e a experiência negra no Brasil", Projeto História I2, (I995), pp. 43-56. See also Antonio Luigi Negro and Flávio Gomes, "Além de senzalas e fábricas. Uma história social do trabalho", Tempo Social. Revista de sociologia da USP, I 8: I (2006), pp. 2 17-240. I6. Nevertheless, this perspective is far from unanimous among historians of slavery in Brazil, and many of them would not consider their field as part of labour history or even see the latter as connected to the former.

17. The section on "The rule of law" in Thompson's Whigs and Hunters had a particularly strong impact on Brazilian labour historians doing research on the Vargas era, as well as in the debates regarding the long process of emancipation of slaves in the nineteenth century. See. E.P. Thompson, Whigs and Hunters. The Origin of the Black Act (New York, 1975). Thompson's work has constituted a major influence on Brazilian historiography and the study of its reception has itself become a recurrent topic of enquiry. See, for instance: Marcelo Badaró Mattos, E. P. Thompson e a tradiçao de crítica ativa do materialismo histórico (Rio de Janeiro, 20I2); Antonio Luigi Negro, "E.P. Thompson no Brasil. Recepção e usos”, Crítica Marxista, 39 (20I4), pp. I I I-I6I; Francisco Barbosa de Macedo, "O (re)fazer-se da historiografia. A obra de E.P. Thompson na produção discente do Programa de Pós-Graduação em História da Unicamp (1982-2002)” (Ph.D., Universidade de São Paulo, 2017).

I 8. José S.L. Lopes, A tecelagem dos conflitos de classe na 'cidade das chaminés' (São Paulo/ Brasília, I988); José R. Ramalho, Estado-patrão e luta operária. O caso FNM (São Paulo, I989); Paulo Fontes, Trabalhadores e cidadãos. Nitro Quimica: a fábrica e as lutas operárias nos anos 50 (São Paulo, I997); Alexandre Fortes, Nós do quarto distrito. A classe trabalhadora porto-alegrense e a Era Vargas (Rio de Janeiro [etc.], 2004); João José Reis and Eduardo Silva, Negociação $e$ Conflito. A resistência negra no Brasil escravista (São Paulo, 1989); and Sidney Chalhoub Machado de Assis, Historiador (São Paulo, 2003). 
democratic movements of pre-I9I4 Europe”. In this regard, the agenda of Brazilian labour history has also undergone important transformations. ${ }^{19}$

The political success of this new generation of activists - both from unions and from other social movements - turned them increasingly into officials of sizeable organizations, as well as members of legislative bodies and governments, initially at the local and state levels. In dialogue with those contemporary experiences, historical research started to re-examine processes of institutionalization of the labour movement in the past, thereby directing attention again to the years between 1930 and 1964 , i.e. the Vargas era and its aftermath. ${ }^{2 \circ}$ The huge presence of migrants from the countryside in this new industrial working class inspired historians to challenge traditional views of rural backwardness and those academic analyses, which had emphasised internal migration as an obstacle to working-class formation. ${ }^{2 \mathrm{I}}$ The struggles for the enforcement of the new social rights established by the I 988 Constitution gave another impulse to study this period and the similar experiences of conflicts surrounding the compliance with labour laws. ${ }^{22}$ Although the I 990 s brought a deeply changed political and economic environment with the neoliberal presidencies of Fernando Collor de Mello (1990-1992) and Fernando Henrique Cardoso (1995-2002), the focus of Brazil's (by now academically institutionalized) labour history remained on the populist experience, further deepening the revisionist view of populism, which had already begun in the I 980 s and which offered readings that were both more nuanced and appreciative of the corporatist system established by the Getúlio Vargas governments (1930-1945; 1950-1954). ${ }^{23}$

19. Eric J. Hobsbawm, The Age of Extremes. The Short Twentieth Century, I9I4-I99I (London [etc.], 1994), p. 370.

20. Alexandre Fortes, "Revendo a legalização dos sindicatos. Metalúrgicos de Porto Alegre (193 I-1945)", in Alexandre Fortes et al., Na luta por direitos. Estudos recentes em história social do trabalho (Campinas, 1999), pp. 19-49; Angela M.C. Araújo, "Estado e trabalhadores. A montagem da estrutura sindical corporativista no Brasil", in idem, Do corporativismo ao neoliberalismo. Estado e trabalhadores no Brasil e na Inglaterra (São Paulo, 2002), pp. 29-57.

21. Paulo Fontes, Migration and the Making of Industrial São Paulo (Durham, NC, 2016); Antonio Luigi Negro, Linhas de montagem. O industrialismo nacional-desenvolvimentista e a sindicalização dos trabalhadores, 1945-1978 (São Paulo, 2004); Murilo Leal, A Reinvenção da Classe Trabalhadora, $1953-1964$ (Campinas, 201 I).

22. Maria Celia Paoli, "Trabalhadores e cidadania. Experiência do mundo público na história do Brasil moderno", Estudos Avançados, 3:7 (1989), pp. 40-66; John D. French, The Brazilian Workers' ABC. Class Conflict and Alliances in Modern São Paulo (Chapel Hill, NC, 1992); Hélio da Costa, Em busca da memória (Comissão de Fábrica, Partido e Sindicato no Pós-guerra) (São Paulo, I995); Fernando Teixeira da Silva, A carga e a culpa. Os operários das docas de Santos. Direitos e cultura de solidariedade, 1937-1968 (São Paulo/Santos, I995); and idem, Trabalhadores no Tribunal. Conflitos e Justiça do Trabalho em São Paulo no Contexto do Golpe de 1964 (São Paulo, 20I6).

23. Ângela de Castro Gomes, $A$ invenção do trabalhismo (Rio de Janeiro [etc.], I988); John D. French, Drowning in Laws. Labor Law and Brazilian Political Culture (Chapel Hill, NC, 2004); 


\section{0-2016: MUNDOS DO TRABALHO ON THE UPSWING}

Around 2000, the political pendulum in Brazil, just as in many other Latin American countries, was veering to the left. The celebration in $200 \mathrm{I}$ in Porto Alegre of the first edition of the World Social Forum gave the movements against neoliberal globalization, which had become visible during the previous years, a (however vague) political platform. The venue Porto Alegre was not a coincidence, as the city had, under the aegis of the PT, implemented a series of quite challenging social and political reforms, including the famous "participatory budget". More importantly, in 2002, Luiz Inácio Lula da Silva, the former north-eastern migrant and historical leader of the metalworkers, was elected as president. In this general context, Brazilian labour history further consolidated as a specialized historiographical field. A year earlier Mundos do Trabalho, a network of labour historians within the Brazilian Historical association ANPUH (Associação Nacional de História) was established. ${ }^{24}$ It was, from the beginning, not only marked by the spirit of political opening experienced at that moment in Brazil, yet also by a broadened and inclusive definition of the concerns of labour history: historians working on all periods (including before 1900) and all regions (not only the centres of industries) were invited to participate. In addition, both urban and rural, formal and informal, as well as free and unfree labour were included. As a result of this "ecumenical perspective", 25 in the last twelve years this workgroup has organized a series of national and international conferences in which hundreds of researchers, many of them graduate students or young professors, take part on a regular basis.

Such a broadened outlook on labour was very much in tune with the politics of inclusion of the PT, which did not limit its social policies to industrial workers, particularly those organized and represented by unions. There is no space here to give a detailed assessment of the thirteen years of Workers Party rule in Brazil and all its contradictions and achievements. While it seemed clear from early on that the political and economic orientation of Lula's government would be definitely among the "pinker" streams of the new "red wave" in Latin America, its actions called the attention of many observers worldwide, not least because of the size of the

Barbara Weinstein, For Social Peace in Brazil: Industrialists and the Remaking of the Working Class in São Paulo, 1920-1964 (Chapel Hill, NC, 1996).

24. See: https://gtmundosdotrabalho.org; last accessed 7 November 2017. Apart from regular academic gatherings and congresses, since 2009 it publishes an academic journal with the same name. See: https://periodicos.ufsc.br/index.php/mundosdotrabalho/index; last accessed 7 November 2017.

25. As mentioned before, this integration of different research fields is an ongoing quest that, despite its numerous successes, has not undone the existence of separate research communities something that is well reflected in the number and names of working groups within ANPUH. 
country (which is not only quasi-continental in territory, but the sixth in population) as well as the fact that it is one of the most industrialized countries in the Global South. Among the undeniable successes of the Lula years are the effective measures adopted to face the most dramatic results of the abysmal social inequalities in Brazil, seeing millions of households overcoming hunger and poverty. Furthermore, several years of economic growth and low unemployment rates in a political environment favourable to union activity and the effects of substantial rises in the national minimum wage increased workers' share in national income and their collective bargaining power. ${ }^{26}$ On a different plane, Brazil was also able to attain a new position geopolitically, playing a central role among the BRICS countries and contributing to the weakening of the hegemony of the US over Latin America and the Caribbean.

New laws extended labour rights to categories historically kept in the informal sector, such as domestic workers. A series of measures were adopted to address the pervasive racial inequalities in Brazil (including affirmative action policies and quotas for public universities), thus abolishing not only the myth of Brazil as a harmonious "racial democracy", but giving the historical legacy of slavery a new relevance in public discourse. The acknowledgement of the continuing presence of unfree labour (called "contemporary slavery") led to improved laws to combat it; similar measures were taken against child labour. In the same vein, issues of gender were addressed in various ways. These outstanding achievements created a dynamic dialogue as well as many instances of cooperation between, on the one hand, a state that experienced a partial elite change with many former activists now in official positions, and, on the other hand, organizations from both the labour and "new" social movements. At the same time, this relationship was contentious from the outset (and increasingly so over the years), with many moments of conflict and alienation between movements and the government.

26. The literature analysing Brazil's recent development and the PT government, of course, fills libraries. For interventions from a labour history and labour studies perspective, see Alexandre Fortes and John D. French, "Another World Is Possible: The Rise of the Brazilian Workers' Party and the Prospects for Lula's Government", Labor: Studies in Working-Class History, 2:3 (2005), pp. I3-3I; André Singer, "Raízes sociais e ideológicas do lulismo", Novos Estudos - CEBRAP, 85 (2009), pp. 85-I02; Alexandre Fortes, "In Search of a Post-Neoliberal Paradigm: The Brazilian Left and Lula's Government", International Labor and Working-Class History, 75:1 (2009), pp. 109-125; André Singer, "A segunda alma do Partido dos Trabalhadores", Novos Estudos - CEBRAP, 88 (2010), pp. 89-III; Perry Anderson, "Lula's Brazil", London Review of Books, $33: 7$ (20I I), pp. 3-I 2; John D. French and Alexandre Fortes, "Nurturing Hope, Deepening Democracy, and Combating Inequalities in Brazil: Lula, the Workers' Party, and Dilma Rousseff's 2010 Election as President", Labor: Studies in Working-Class History, 9:I (2012), pp. 7-28; André Singer, Os sentidos do lulismo. Reforma gradual e pacto conservador (São Paulo, 20I 2). 
The economic and political foundations on which that progressive moment of Brazilian history rested, however, had built-in contradictions that began to gradually exacerbate, eventually erupting into a crisis that led to the judiciary-parliamentary coup of 20I6. On one hand, the political system of coalitional presidentialism led to the formation of highly contradictory alliances between the Workers Party and sectors of the political right, for the sake of governability. ${ }^{27}$ On the other hand, the dependency on the commodities boom as a source of economic prosperity also implied a coexistence, if not cooperation, with an agribusiness that was responsible for great environmental destruction and involved in the most degrading forms of labour exploitation. The growth of such giant state-owned companies as Petrobras as well as major investments in infrastructure for the 20I4 World Cup and the 20I6 Olympic Games at the same time created the opportunity for large-scale corruption.

As tensions on all those fronts mounted, the second term of former guerrilla fighter Dilma Rousseff, Brazil's first female president, was increasingly confronted with attacks by a powerful alliance of the policejudiciary apparatus, media groups, and new right-wing groups active in social networks and street demonstrations. Meanwhile, the PT had gradually lost the support of many who were disenchanted with the Realpolitik associated with government politics. More importantly, the PT, which had once been held up as a "new type of party" due to its ability to give social movements ample space, ${ }^{28}$ had been drained of most of its previous movement components. When it came under attack, there was not enough "movement" left to defend it. ${ }^{29}$

It seems evident that labour history in Brazil during the last fifteen years has been related, to a high degree, to the particular conjuncture the country has gone through - the articles assembled in this Special Issue bear witness to an atmosphere, both intellectually and politically, in which concerns of inclusion, participation, and social justice were given ample space. At the same time, labour historians in Brazil responded to a series of internal dynamics specific to academia in general and historiography in particular, both originating in the country itself and in international debates. Indeed, Brazilian labour historians have become increasingly internationalized since 2000. They have started to attend international conferences and

27. On the peculiarities of Brazilian presidentialism, see Fernando Limongi, "Democracy in Brazil: Presidentialism, Party Coalitions and the Decision Making Process", Novos Estudos - CEBRAP, 3 (selected edition) (2007), available at: http://socialsciences.scielo.org/scielo.php?script=sci_arttext\& pid=SoIOI-33002007000I0000 I\&lng=en\&tlng=en; last accessed 7 November 2017.

28. Michael Löwy, "A New Type of Party: The Brazilian PT", Latin American Perspectives, I $4: 4$ (1987), pp. 453-464.

29. Alexandre Fortes, "Brazil's Neoconservative Offensive", NACLA Report on the Americas, 48:3 (2016), pp. 217-220; Perry Anderson, "Crisis in Brazil", London Review of Books, $38: 8(2016)$, pp. I 5-22. 
seminars more frequently, and to publish in some of the major academic journals of the field. ${ }^{30}$ Their academic connections and networks have expanded beyond the traditional links with the US and Europe. There has been a growing presence of scholars from all over Latin America, as well as from India and Africa in the biannual conferences organized by Mundos do Trabalho. Its electronic journal, publishing articles in Portuguese and Spanish, is probably now the most important in the field in Latin America. In recent years, a growing number of Brazilian scholars are getting involved in research projects with comparative, transnational, and connected approaches, and interest in methodological and theoretical discussions on Global Labour History has risen. ${ }^{3 \mathrm{I}}$

In spite of all these developments and achievements, Brazilian labour history remains, to a great extent, parochial and self-centred. There are many reasons for that, among them, language insularism and a resilient methodological nationalism. For instance, the fact that, for many decades, most of the scholarship was limited to the two most important states in economic and political terms (São Paulo and Rio de Janeiro) has engendered a huge demand for research on other regions within the borders of Brazil rather than a thrust to go extra muros. The international diffusion of the

30. Some recent and representative examples are Fernando Teixeira da Silva, "The Brazilian and Italian Labor Courts: Comparative Notes", International Review of Social History, 55:3 (2010), pp. 38I-4I 2; Marcelo Badaró Mattos, "Experiences in Common: Slavery and 'Freedom' in the Process of Rio de Janeiro's Working-Class Formation (1850-1910)", International Review of Social History, 55:2 (2010), pp. 193-2 I 3; Sidney Chalhoub, "The Precariousness of Freedom in a Slave Society (Brazil in the Nineteenth Century)", International Review of Social History, 56:3 (20I I), pp. 405-439; Leonardo Pereira, "The Flower of the Union: Leisure, Race, and Social Identity in Bangu, Rio de Janeiro (1904-1933)”, Journal of Social History, 46:I (2012), pp. I 54-169; Cristiana Schettini, "South American Tours: Work Relations in the Entertainment Market in South America", in Ulbe Bosma et al. (eds), "Mediating Labour: Worldwide Labour Intermediation in the Nineteenth and Twentieth Centuries", Special Issue 20 of International Review of Social History, 57 (201 2), pp. I 29-160; Paulo Fontes and Francisco B. Macedo, "Strikes and Pickets in Brazil: Worker Mobilization in the 'Old' and 'New' Unionism, the Strikes of 1957 and I980", International Labor and Working Class History, 83 (2013), pp. 86-I I I; Henrique Espada Lima, "Wages of Intimacy: Domestic Workers Disputing Wages in the Higher Courts of Nineteenth-Century Brazil", International Labor and Working Class History, 88 (201 5), pp. I I-29; Clarice Speranza, "European Workers in Brazilian Coalmining, Rio Grande do Sul, I850-1950", in Ad Knotter and David Mayer (eds), "Migration and Ethnicity in Coalfield History: Global Perspectives", Special Issue 23 of International Review of Social History, 60 (20I 5), pp. I65-I 83 ; Fernando Teixeira da Silva and Larissa Rosa Corrêa, "The Politics of Justice: Rethinking Brazil's Corporatist Labor Movement”, Labor: Studies in Working-Class History, I 3:2 (2016), pp. I I-3 I. Also see the contributions to Paulo Fontes and Alexandre Fortes (eds), "Space, Culture and Labour: Brazilian Urban Workers in the Twentieth Century", Special Issue of Moving the Social: Journal of Social History and the History of Social Movements, 49 (2013).

3I. An overview of recent trends and their connections to the political context is provided in John D. French and Alexandre Fortes, "When the Plumber(s) Come to Fix a Country: Doing Labor History in Brazil”, International Labor and Working-Class History, 82 (2012), pp. I 17-I 26. 
scholarly works and of the rich debates that characterize the field of labour history in Brazil is thus still relatively timid, and, consequently, their contribution to the international historiographical debates until this point, has fallen short of its potential.

At the same time, this situation is not only a result of "shortcomings" and "deficiencies", but also of a degree of hesitancy, if not resistance: It is important to bear in mind that many Brazilian historians (like their colleagues in other Latin American countries) have received the "global turn" announced for historiography with some scepticism and mistrust. Labour history is no exception in this regard. The proclaimed newness of Global Labour History has been disputed and is considered by many as a typical exaggeration of international academic vogue. Some, indeed, see it as just another hegemonic Western academic project, pointing to the continuing asymmetries and hierarchies (both academically as well as in relation to the working and living conditions of historians), the dominance of English as lingua franca, etc. The agenda of Global Labour History still seems mainly set by the North, its academia, institutions, and journals. In addition, there are concerns that the current debates in Global Labour History tend to neglect power relations, potentially resulting in a "depoliticization" of the field, an issue particularly sensitive in Brazil and Latin America in general. ${ }^{32}$ Scepticism is also voiced vis-à-vis those approaches that seem to privilege a return to macro-narratives with an emphasis on economic processes on a global scale. Many historians fear that their focus on local and micro scales could be buried by the global "wave". More importantly, many argue that these sort of global approaches risk erasing working-class experiences from the labour history narrative, something that is considered one of the most important gains of the field in the last three decades. ${ }^{33}$

32. See, for instance, a comment by Peter Winn, who asserts this political dimension and argues that labour history in Latin America remains, due to this political urgency, mostly centred on each national society and is thus not easily compatible with the enterprise of Global Labour History: Peter Winn, "Global Labour History: The Future of the Field?", International Labor and Working-Class History, 82 (2012), pp. 85-91.

33. These sceptical views persist despite the fact that most of the concerns summed up here have been repeatedly and self-critically addressed in the conceptual propositions about Global Labour History that insist on both a continued focus on agency and the open and collaborative character of Global Labour History as a "field of concerns" rather than a "paradigm". A proper debate about why these proclamations have not succeeded so far in fully convincing the sceptics would be worthwhile. Among the numerous propositions in that vein, see, for instance: Marcel van der Linden, "Labour History: The Old, the New and the Global", African Studies, 66:2-3 (2007), pp. I69-I80; Leo Lucassen, "Working Together: New Directions in Global Labour History", Journal of Global History, I I:I (20I6), pp. 66-87. For Anglophone critical interventions that echo the concerns of many Brazilian and Latin American labour historians listed above, see, for instance, Dorothy Sue Cobble, "The Promise and Peril of New Global Labor History", International Labor and Working-Class History, 82 (2012), pp. 99-107; Fred Cooper, "What Is the Concept of Globalization Good For? An African Historian's Perspective", African Affairs, I00 (200I), pp. I89-213, 
The interrelation between labour history in Brazil and Global Labour History is thus not a readily smooth or congenial one, but a dialogue that must be constructed. Consequently, the main aims of this Special Issue are to strengthen the links and to improve this dialogue. We wanted to ensure that the contributions by Brazilian labour historians go beyond "interesting" cases and examples in an otherwise well-contoured intellectual project, and aspire to co-shape the core discussions in Global Labour History. The nine articles assembled here offer a rich sample of the current state of the field in Brazil and certainly the most comprehensive compilation on Brazilian labour history ever published in English. They encompass a wide geographical scope, with studies ranging from the Amazon region to the extreme South, through the north-east and the central areas of São Paulo and Rio de Janeiro. In chronological terms, the articles brought together in this Special Issue also express the recent trend of integrating studies on periods before 1900 into labour history. ${ }^{34} \mathrm{~A}$ broad array of workers (slaves, maids, prostitutes, industrial workers, rural workers, etc.) is covered. At the same time, this volume also presents a renewed historiography of movements and organizations, offering insights both on workers' collective actions and everyday life experiences, as well as on the workers' relations to institutions, the state, and politics. The topics explored by the authors resonate deeply with some of the central debates in Global Labour History, such as free and unfree labour; labour in "frontier" environments; the transnational circulation of militants and ideas; gender, race, and class; labour laws and the State; labour and space; populism, patronage, and workers; labour movements in an international perspective; or experiences of labour under dictatorships. Research problems are addressed through a diversity of methodologies, with the employment of a broad range of sources, producing innovative approaches and results. As non-familiar readers will notice when reading the articles in this Special Issue, Brazilian labour historians share numerous concerns with their counterparts in other countries; at the same time, there are some issues and perspectives that are quite specific to them. In the following, we will highlight some of these commonalities and specificities by introducing the contributions to this Special Issue along certain larger themes, such as "free/unfree" labour; the use of judiciary sources; the interlocking identities of "gender", "race", and "class"; the continuing currency of topics of political history and the history of movements; transnational and comparative perspectives; and the

and Neville Kirk, "Transnational Labor History: Promises and Perils", in Leon Fink (ed.), Workers across the Americas: The Transnational Turn in Labor History (Oxford, 201 I), pp. I 8-22.

34. Earlier periods have not yet tended to be in the focus of Brazilian labour history, although it seems evident that studies on the colonial period - again, taking the example of the historiography on slavery - should be integrated in the debates. This remains one of the main challenges for Brazilian labour history. 
necessary integration of labour history with the history of New social movements. 35

\section{FLUID BOUNDARIES AND INTERLOCKING IDENTITIES - “FREE/UNFREE”, “GENDER”, AND “RACE”}

One of the perennial topics in the current international debate is the interrelation of free and unfree labour (and the manifold transitions between them), a debate to which Brazilian labour history has already made important contributions and which, indeed, has been one of the central concerns of the events of the ANPUH working group Mundos do Trabalho. ${ }^{36}$ In this Special Issue, this tradition is further enhanced: In "Free and Unfree Labor in the Nineteenth-Century Brazilian Amazon", Adalberto $\mathrm{Paz}$ presents important findings on the still little-known characteristics of compulsory labour in the Northern areas of Brazil and its complex relations to the legal status of different ethno-racial groups. Paz analyses the different legal regulations vis-à-vis those coloured population groups who were not enslaved - indigenous, mestiços, libertos, etc. - and focuses on the ambiguities of the official claims that granted freedom to the indigenous population. While several attempts to introduce African slave labour as a replacement failed, the authorities resorted to changing, but continuous strategies to install regimes of forced labour (for both public and private work assignments) during the eighteenth and nineteenth centuries. Finally, adding a component of transnational history, $\mathrm{Paz}$ points to the strong connection between this kind of forced labour and the strategic operations implemented by the postcolonial Brazilian Empire (I 822-I889) in order to defend its territorial control of the Amazon against French claims.

Fabiane Popinigis and Henrique Espada Lima further advance the current debate about the blurred boundaries not only of "free" and "unfree" labour", but also between the "domestic" and "non-domestic" spheres. In "Maids, Clerks, and the Shifting Landscape of Labor Relations in Rio de Janeiro (I 830s-I 880s)", they explore the connections between class, gender, and race during the last decades of legal slavery and the onset of European

35. A caveat should be added at this point: This introduction claims the contributions to the present Special Issue as "players" of a larger "team", namely Brazilian labour historiography. It goes without saying that such an engrossing attribution is debatable and that each article can be read as part of other intellectual or geographical affiliations.

36. As has been recently shown in a detailed analysis of the meetings and conferences of Mundos do Trabalho, papers related to topics of "free/unfree labour" (including "slavery") made up about one third of all papers presented between $200 \mathrm{I}$ and $20 \mathrm{I} 5$ at the groups' symposia. See Paulo Cruz Terra and Fabiane Popinigis, "As diversas formas de exploração do trabalho e de organização dos trabalhadores no âmbito da produção do GT Mundos do Trabalho", paper presented at the Congreso Latinoamericano y del Caribe de Trabajo y Trabajadores, 2-8 May 2017, La Paz. 
mass immigration to Brazil. Making ample use of judicial sources, they highlight, through a number of vivid accounts of workers' experiences, important shifts during those years: Women, especially of Afro-Brazilian descent, were pushed out of small commercial establishments and street vending, turning the work of "clerks" into the domain of male, non-slave labourers, while domestic labour at the same time became more precarious and female.

Issues of "free" and "unfree" labour are further addressed in the article by Christine Rufino Dabat and Thomas Rogers about a group of workers that has, for most of Brazil's history, constituted the majority of workers, but which has often been neglected as a topic in labour history: rural workers. In their article about "Sugarcane Workers in Search of Justice: Rural Labour through the Lens of the State", they analyse two locations during the I960sI 980 s in the cane zone of Pernambuco, historically one of the centres of slave-based plantation production. At the beginning of the i960s, these workers got access to the Brazilian system of labour courts (Juntas de Conciliação e Julgamento, JCJs). Using files from these courts both for an aggregate analysis of the situation of this group and for reconstructing some individual cases, it becomes clear that these workers were exposed to a number of onslaughts and impositions that placed them outside a "normal" labour relationship. The collusion of propertied groups and judiciary elites played an important role in enabling this situation, which persisted despite the existence of such regulatory bodies as the labour courts. By referring to a number of current studies on different world regions about the precariousness of workers, especially in contexts in which, historically, unfree labour has set the frame for labour exploitation and in which the access to land, education, etc. continues to be extremely limited, Dabat and Rogers highlight the degree to which violence and dynamics of exclusion have characterized the life of these workers. This is reinforced by a symbolical exclusion that came with condescending elite views about the rural as "backward" and "archaic".

Both the contributions by Fabiane Popinigis and Henrique Espada Lima as well as the one by Thomas Rogers and Christine R. Dabat point readers to a peculiarity of Brazilian labour history: the extensive use of judicial sources as a way to reconstruct not only aggregate social realities, but also the voices of individual workers. This methodological predilection (which indeed sets an important example for labour historians in other countries) has a strong tradition in Brazil and might be attributed to a number of factors: While Brazil was the last country in the Americas to abolish slavery, it has seen more freed slaves and free people of colour than any other of America's slave-based societies. This combination of "free" and "unfree" favoured that, in the long, drawn out process of the abolition of slavery during the years of the Empire (1822-1 888), both enslaved and free AfroBrazilians submitted cases to the courts, thereby leaving unique written 
traces of their claims and doings. Still more importantly, there is a powerful tradition of labour law in Brazil. As Aldrin Castellucci and Benito Bisso Schmidt point out in their article "From the Streets to the Government: Socialist Militants and Labour Law in Brazil", leading socialists of the Frist Republic (I889-1930), many of whom rose socially by studying in one of the country's law schools, shared a strong orientation towards a legal regulation of the labour-capital relation. Yet, it was especially since the "Revolution of 1930" and the beginning of the corporatist era of Getúlio Vargas (I930-I945; I95I-I954) that "labour law" became a central prism through which pro-worker policies were formulated and the relationship between labour, capital, and the state has been regulated. This culminated, in 1943, in the Consolidated Labour Laws (Consolidação das Leis do Trabalho, CLT), probably the most comprehensive and systematic legal body of labour regulation on the subcontinent. It has led historians to read the history of labour through the evolution of this body and to a keen sensitivity for the documentary potentials of one of its major institutions, the labour courts. ${ }^{37}$ The records of these courts are not universally available, with many documents lost; yet, in a number of states (Rio Grande do Sul, Pernambuco, São Paulo, Bahia, among others) these have been preserved, at least partially, often with the help of attentive historians, and are explored today for a number of research questions.

Cristiana Schettini's contribution to the Special Issue brings in a group that has long been completely neglected by labour historians: sex workers. Focusing on the labour relations in the Mangue, one of Rio de Janeiro's red light districts in the I920s, she combines a variety of sources to follow different trajectories: League of Nation's investigators (some of them undercover), local Brazilian authorities, particularly the police, and Fanny Galper, a former prostitute and madam. "Between Rio's Red-Light district and the League of Nations: Immigrants and Sex Work in I920s Rio de Janeiro" integrates concerns of gender, race, urban history, social thought, and policymaking in order to gain a fuller understanding of the (highly racialized) work relations in sex work at the time, the forms of transnational mobility involved, Rio's specific policy of surveillance, and the international circulation of policies to regulate prostitution. Meanwhile, by focusing on one actor, the doings and voice of one of these women is partly preserved, allowing fascinating insights in the trajectory of a sex worker ascending to become a relatively well-to-do entrepreneur.

Cristiana Schettini's article also points to the interlocking identifications of gender, class, and race: She makes clear that the relation between such

37. For a general historical analysis of these labour courts, see the contributions to Ângela de Castro Gomes and Fernando Texeira da Silva (eds), A Justiça do Trabalbo e sua história. Os direitos dos trabalhadores no Brasil (Campinas, 2013). 
prostitutes-turned-madams of European Jewish origin like Fanny Galper and the Afro-Brazilian sex workers who toiled for her was marked by inequality and exploitation. Racialized social hierarchies as mechanisms for defining different groups of workers (and their legal status) have played a fundamental role in Brazilian society, and they are also highlighted by Adalberto Paz for the Amazon, by Fabiane Popinigis and Henrique Lima for nineteenth-century Rio, and by Christine Dabat and Thomas Rogers for the mostly Afro-Brazilian cane workers in Pernmabuco. Also among the six biographies of socialists analysed by Aldrin Castellucci and Benito Bisso Schmidt (a political group that many would associate with "European immigrants"), two were of "mixed" Afro-Brazilian descent. Questions of race have recently gained increasing importance among Brazilian labour historians, thus breaking the previous tendencies of giving attention to Afro-Brazilians as slaves only, while "invisibilizing" their presence in the worlds of labour in the periods after abolition. ${ }^{3}$ Such tendencies have echoed one of Brazil's central myths since the late I940s, namely that it is a country of "racial democracy" in which all groups live in "harmony" thus making issues of race obsolete. Brazilian labour history (as well as many other fields of scholarly enquiry) is currently contributing to a deconstruction of this myth.

\section{POLITICAL HISTORY REVISITED}

As mentioned before, one of the specific characteristics of labour history in Brazil (and in Latin America in general) is the continuing currency of political history as well as the history of labour movements and organizations. This is a sensible difference to the debates about Global Labour History in Europe, which, in recent years, have tended to focus on social histories of work and labour relations (no wonder, one of the major critiques of Latin American labour historians vis-à-vis certain approaches of Global Labour History is its "depolitization" and supposed lack of attention to asymmetric power relations). Such "traditionalism", however, should not be equated with "conventionalism", and several contributions to this Special Issue illustrate how questions of political history can be enhanced by a number of fresh perspectives - often using comparisons or transnational connections to revisit certain issues. In "Revolutionary Syndicalism and Reformism in Rio de Janeiro's Labour Movement (1906-1920)", Claudio Batalha provides an updated panorama of the differences and commonalities that characterized the most important

38. See, for instance, several of the contribution to: Alexandre Fortes and Habe Mattos, "Post- Abolition in the Atlantic World", Dossier of the Revista Brasileira de História, 35:69 (2015), available at: http://www.scielo.br/scielo.php?script=sci_issuetoc\&pid=0 I02-0 I $8820 \mathrm{I} 5000 \mathrm{I} \& \operatorname{lng}=\mathrm{en} \& \mathrm{x}$ $\mathrm{nrm}=\mathrm{iso}$; last accessed 7 November 2017. 
political currents inside Rio's unionism during the Brazilian First Republic. He not only proceeds to question a number of established myths (for instance, about a supposed "anarchist hegemony" at that moment), more importantly he shows how apparently stable attributes such as "reformist" or "revolutionary syndicalist" were much more fluid and porous than usually admitted. Contrasting Rio with both the European "models" of each of these currents (and their associated practices and positions) and the sometimes markedly different outlook of corresponding currents in Brazil's other industrial centre at the time, São Paulo, Batalha proceeds to show that "revolutionary syndicalism" in Rio was never very "revolutionary" (curiously, in contrast to the city's rebellious traditions), and that, despite the sometimes bitter struggles with "reformists", collaboration between the two currents was common. Furthermore, he shows that the "revolutionary syndicalists" pushed for (and actually gained) a number of reforms during the years I917-1919, i.e. during a cycle of struggles that has often been associated with "revolution". Through a detailed analysis of local activities and sources as well as by comparing them to similar practices in other places (both in Brazil and internationally), Batalha achieves important nuances for a field of political action that previously was often depicted as organized in clear-cut blocks.

In a similar vein, Aldrin Castelucci's and Benito Bisso Schmidt's article "From the Streets to the Government: Socialist Militants and Labour Law in Brazil" uses a comparative biographical analysis of a group of socialists to highlight nuances, contradictions, and counterintuitive facts about a political current whose "performance" had long been viewed as unequivocally negative and problematic in terms of "selling out", first, to the oligarchic block predominating during the First Republic, then to the corporatist regime emerging after 1930 under Getúlio Vargas. Yet, the important and usually overlooked continuities between the experiences of the labour movement in the early twentieth century and the Vargas era is precisely the point of Castelucci's and Schmidt's argument: Older readings of a straightforward "cooptation" of these actors into the new regime are too simple, they say. They assert that the six individuals analysed did not experience too much of a rupture between their earlier (sometimes surprisingly militant) activities and their later role as legal advisors and officials to the Vargas regime. They also argue that they succeeded in actually connecting the struggles of the workers during the first three decades of the twentieth century to the reforms and legal provisions in favour of workers since 1930 .

The transnational "lens" has, without doubt, been a powerful enhancement in labour history during the last decades. It has allowed for both the breaking of new ground and the re-interpreting of old questions. Christina Schettini's story about sex workers in Rio points to the potential of this "lens" for a social history of labour, allowing the movements of workers 
whose lives are marked by migration and diverse cross-border contacts to be traced. The political history of labour and its movements has equally benefitted from such transnational perspectives. As Alexandre Fortes illustrates in his article, they enable new interpretations of one of the most perennial topics of Latin American labour history: to understand the origins and the rise of populism in general, and the allegiance of workers to it in particular. The literature on populism, especially on the trinity of Argentinian Peronism (1943/45-1955), Mexican Cardenism (1934-1940), and Brazilian Varguismo (after the reign of Getúlio Vargas, 1930-1945; I95I-1954) fills libraries; yet, in Brazil, as elsewhere, it is largely dominated by approaches that see each of these phenomena as nationally isolated and idiosyncratic, to a point where the category of "populism" itself is rejected as too generic. However, there is a noticeable new interest in more comparative and transnational views in the study of Latin American populisms. ${ }^{39}$ Adding to this fresh departure, Alexandre Fortes, in "World War II and Brazilian Workers: Populism at the Intersections of National and Global Histories", argues that the connections between total war on the one hand, and changes in labour relations and social rights on the other (otherwise a well-established topic in the international historiography), have been largely ignored in Brazil as a result of these limitations. In dialogue with other historiographies, particularly on foreign relations, economic development, and military history, the author emphasizes how Brazil's involvement in World War II reinforced or even enabled a series of transformations within Varguismo, among them the further inclusion of workers through a series of social reforms and the emergence of mass nationalism with a considerable mobilizational component - something that the Vargas regime, untypically for Latin American populisms, had previously been lacking. During and through its involvement in World War II, Varguismo thus evolved into a regime more akin to the political systems discussed under the label "populism".

Combining both comparative and transnational perspectives, Larissa Corrêa's article "Looking at the Southern Cone: American Trade Unionism

39. For a comparative advance on historical populisms published before 2000, i.e. before "populism" made a spectacular comeback in Latin America; see María Moira Mackinnon and Mario Alberto Petrone (eds), Populismo y neopopulismo en America Latina. El problema de la Cenicienta (Buenos Aires, 1998). More recent suggestions for a comparative and transnational reinterpretation are offered, for instance in: Matthew B. Karaush, "Populism as an Identity: Four Propositions on Peronism", in John Abromeit et al. (eds), Transformations of Populism in Europe and the Americas. History and Recent Tendencies (London, 2016), pp. 197-2 I I. Interestingly, the Argentinian Network for the study of Peronism has, for the first time, included a stream on "comparative, regional, and transnational studies" for its next conference. See Call for Papers, 6th Conference on the Study of Peronism, University of Buenos Aires, 29-3 I August 2018, available at: http://redesperonismo.org/wp-content/uploads/2017/ro/First-Annoucement_6thConference-on-the-Study-of-Peronism.pdf; last accessed 7 November 2017. 
in the Cold War Military Dictatorships of Brazil and Argentina" analyses the views and actions of AFL-CIO-affiliated organizations active in Latin America. Focusing on the American Institute for Free Labor Development (AIFLD) and comparing its activities in Brazil and Argentina during the I960s and I970s, she shows the degree to which the policies developed vis-à-vis Brazil - especially during and after the military coup of I964 served as a model for their actions in Argentina and other countries. While its outlook remained fully formatted by a Cold War rationale, they found it difficult to find interlocutors in the two countries as the local union movements were either under a left-wing or nationalist (or a left-nationalist) hegemony. A more favourable environment only emerged during the dictatorships, which saw the South American unions assaulted in many ways. While AIFLD directly and indirectly supported these dictatorships, a sensible shift occurred during the last Argentine dictatorship (I 976-I983) with its no-holds-barred, genocidal form of repression, which also affected local contacts and allies of AIFLD. Taking up the "human rights turn" in international politics, the organization now (albeit timidly) confronted these regimes.

What, meanwhile, is a "movement"? Global Labour History aspires to break the divisions between historians of labour movements (however broadly defined) and the so-called New Social Movements. This division echoes some of the political struggles of the i 970 s and after, when New Social Movements claimed to be wholly novel due to their non-affiliation with "labour" as well as its emphasis on other social identifications than "worker" (alternative identifications based particularly on local community and "citizenship", but also on race, gender, or ethnicity). However, as Paulo Fontes points out in his article about the "The Local and the Global: Neighborhoods, Workers and Associations in São Paulo (1945-I964)”, such separations are artificial and should be overcome. Analysing with new archival material a series of mobilization ${ }^{40}$ in early post-war neighbourhoods in São Paulo, he shows the degree to which being a "worker" and a neighbourhood "resident" were interwoven and resulted in processes that combined class formation, political participation, and the building of local community. In order to overcome this disjunction between "workers" and

40. For his research, Fontes strongly relies on records of the Department of Political and Social Order (Departamento Estadual de Ordem Política e Social - DEOPS), founded in the I 920 and of central importance in surveilling all activities of political and social movements both during the Vargas years and the military dictatorship from 1964 on. In the context of the re-democratization process the DEOPS was dissolved in 1983 , its records being preserved and made publicly available in a number of Brazil's states. Today, these archives offer unique insights into the activities of a series of movements, often including otherwise unavailable original documents produced by the movements themselves. For more on DEOPS archives, see Paulo Fontes and Antonio Luigi Negro, "Using Police Records in Labor History: A Case Study of the Brazilian DEOPS", Labor: Studies in Working-Class History, 5:I (2008), pp. I 5-22. 
"neighbours" and the corresponding division between labour history, on the one hand, and social movement studies, on the other, Fontes argues that Global Labour History should also attend more seriously to the "local": it is on the micro-level of neighbourhoods, etc. where such experiences of overlapping identifications and their effects for class formation and political participation can be observed best.

It was our aim to offer readers of this Special Issue more than a showcase of Brazilian labour history and to let the contributions engage with current debates in Global Labour History. In connecting with these ongoing debates in the international field, several contributions break new ground, others revisit topics and cases about which knowledge seemed deceptively final. In order to achieve such dialogue, we have aimed to produce articles that are as comprehensible as possible for all potential readers, including those unfamiliar with Brazil. We hope that colleagues from Brazil or scholars who belong to what, in Europe, is still sometimes called "lusitanistics" will be patient with the repetitive explicitness that this inevitably involves. More than an exchange within a small community, this Special Issue is thus intended as an exercise in the art of "translation": This relates, primarily, to the work of the translators, particularly Amy Chazkel and Bryan Pitts, who have rendered the manuscripts for this Special Issue in English and to whom we owe our gratitude. Translating these manuscripts was a huge effort that went beyond a technical task and involved a myriad of intellectually demanding decisions about notions, idioms, localisms, etc. The task of translation, meanwhile, also involved the authors and ourselves: In two workshops in October 20I5 and December 2016 held at The School of Social Sciences of the Fundação Getulio Vargas (CPDOC/FGV) in Rio de Janeiro previous versions of the articles were discussed not only in relation to their actual content, but also to how such content can be communicated with an audience not familiar with Brazil. We hope that this sample of the ongoing research in Brazilian labour history can serve as both suggestion and inspiration for readers in other parts of the world, helping to further enable a multilateral dialogue in Global Labour History. Such a multilateral dialogue is necessary in order to achieve both a truly global perspective in historical labour studies and, at the same time, to avoid the pitfalls of a closed paradigm under which labour historians in all parts of the world are supposed to follow one single trail. The ongoing task thus remains to build Global Labour History as a pluralistic sphere of scholars who, in the first place, constitute local and macro-regional circuits of debate - each with its own concerns and dynamic, yet interconnected in manifold ways with discussions elsewhere. 